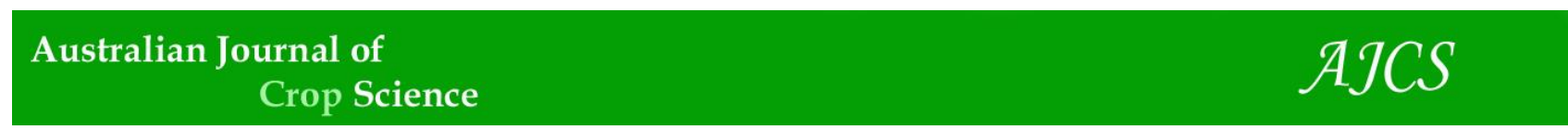

AJCS 12(04):546-551 (2018)

ISSN:1835-2707

doi: 10.21475/ajcs.18.12.04.pne804

\title{
Fungitoxicity activity of Phosphorus and Calcarea carbonica against Sclerotinia sclerotiorum and control of white mold in common bean (Phaseolus vulgaris) with extremely diluted aqueous solutions
}

\section{Bruna Broti Rissato ${ }^{1 *}$, José Renato Stangarlin ${ }^{2}$, Omari Dangelo Forlin Dildey ${ }^{2}$, Camila Rocco da Silva ${ }^{1}$, Edilaine Della Valentina Gonçalves-Trevisoli ${ }^{2}$, Sidiane Coltro-Roncato ${ }^{3}$, Tulya Fernanda Barrientos Webler ${ }^{4}$, Odair José Kuhn ${ }^{2}$, Alfredo José Alves Neto ${ }^{2}$, Diego Augusto Fatecha Fois ${ }^{2}$, Jéssica Caroline Coppo ${ }^{1}$}

${ }^{1}$ State University of Maringá - UEM, Maringá, PR, Brazil

${ }^{2}$ State University of West Paraná - UNIOESTE, Marechal Cândido Rondon, PR, Brazil

${ }^{3}$ University Dynamic of Falls - UDC, Medianeira, PR, Brazil

${ }^{4}$ Federal University of Paraná - UFPR, Palotina, PR, Brazil

*Corresponding author:

\begin{abstract}
Common bean (Phaseolus vulgaris L.) is one of the main Brazilian agricultural crops. Numerous diseases have affected such a crop during its life cycle, such as white mold, caused by Sclerotinia sclerotiorum. This fungus is quite aggressive and requires an intensive use of pesticides. This study aimed at evaluating white mold control and antimicrobial activity against S. sclerotiorum using extremely diluted aqueous solutions of Phosphorus and Calcarea carbonica, at $6 \mathrm{CH}, 12 \mathrm{CH}, 24 \mathrm{CH}, 36 \mathrm{CH}$ and $48 \mathrm{CH}$ dynamizations (centesimal Hahnemannian). The tests were carried out in a completely randomized design, with 10 treatments and 5 replicates each, considering water as control. Variables including disease progression, the number of dead plants, the number of sclerotia, and mycelial growth were evaluated by in vivo and in vitro tests. The treatments Phosphorus $12 \mathrm{CH}$, Phosphorus $48 \mathrm{CH}, \mathrm{Calcarea}$ carbonica $12 \mathrm{CH}$, and Calcarea carbonica $48 \mathrm{CH}$ presented resistance-inducing action by slowing down the disease progression up to $83 \%$ and decreasing the number of dead plants up to $90 \%$. In vitro tests showed that the treatments Phosphorus $12 \mathrm{CH}$, Phosphorus $48 \mathrm{CH}$ and Calcarea carbonica $48 \mathrm{CH}$ slowed down the mycelial growth. The latter also completely inhibited the production of sclerotia. These results indicate the potential of Phosphorus $12 \mathrm{CH}$, Phosphorus $48 \mathrm{CH}$, Calcarea carbonica $12 \mathrm{CH}$, and Calcarea carbonica $48 \mathrm{CH}$ for controlling S. sclerotiorum in common beans.
\end{abstract}

Key words: Alternative control, high dilutions, homeopathy, Phaseolus vulgaris L., repertorization.

Introduction

Common beans (Phaseolus vulgaris L.) are one of the most important edible legumes and Brazilian dietary components, representing the main source of income for a considerable number of farmers (Vieira et al., 2006). For cultivation during the whole year in a large variety of ecosystems, several factors become limiting for common bean production (Vieira et al., 2006). Among these factors, diseases are the main responsible for a low productivity, besides decreasing product quality or even devastating certain areas of cultivation (Vieira et al., 2006). Such diseases include white mold, which is difficult to control and has affected common bean production areas all over Brazil, damages of which can reach $100 \%$ (Napoleão et al., 2005). Thus, based on its aggressiveness grade, besides a wide range of hosts (Fancelli and Dourado Neto, 2007), strategies to control white mold in common beans must be integrated in order to adapt management strategies at the least possible degree of ideal conditions for its development (Pereira et al., 2013). In this context, alternative control methods may be useful to maintain the pathogen population below the economic damage threshold, besides reducing damages to the environment (Vieira et al., 2006) due to the indiscriminate use of pesticides. Among the practices allowed to producers, homeopathy has been included in several agriculture sectors using extremely diluted aqueous solutions, which has also been allowed by the Food and Agriculture Organization of the United Nations (FAO) as a technique to be used in certified organic products (Bonato, 2007a). Homeopathy has been recognized as a field of knowledge with great potential within the modern view of food quality and biosafety, since homeopathic medicine does not leave residues in the environment, vegetables or animal foods. It also provides resources and improvements in plant metabolism, activating reactions involved in the production of enzymes related to plant defense mechanisms (Lisboa et al., 2005).

Since no Homeopathic Materia Medica has been specifically dedicated to plants, the choice of drugs used in agriculture has considered analogies between the symptoms 
described in the Materia Medica and those presented by diseased plants. Thus, the greater levels of evidence between plant symptoms and those described for a remedy, the greater its influence on organism which will be given, and, then, the better the chances for a cure (Wassenhoven, 2007), since homeopathy acts by the similitude principle. Thus, the knowledge about the action of homeopathic remedies on metabolism and in inducing the resistance of cultivated plants may develop a potential and viable alternative for controling plant diseases, including white mold.

Taking all these into account, the aim of this work was to verify the fungitoxic activity of extremely diluted aqueous solutions of Phosphorus and Calcarea carbonica against $S$. sclerotiorum, as well as white mold control on common bean plants.

\section{Results and Discussion}

\section{Resistance inducing activity}

The first trial (Table 1), for area under the disease progress curve (AUDPC), indicated that the Phosphorus treatment differed from the control group in all tested dynamizations, with reductions of $40,58,41,23$, and $58 \%$, respectively. Despite a reduction of $23 \%$ in the progression of white mold was detected by the use of Phosphorus $36 \mathrm{CH}$, it did not reduce the percentage of dead plants (PDP) when compared to the control treatment. However, when tested at $6 \mathrm{CH}$, $12 \mathrm{CH}, 24 \mathrm{CH}$, and $48 \mathrm{CH}$ dynamizations, Phosphorus reduced PDP by $60,90,70$, and $80 \%$, respectively.

Similar results were obtained in the second trial for AUDPC (Table 1), in which all dynamizations tested for the Phosphorus treatment differed from the control group. Such reductions were $36,55,40,26$, and $52 \%$ for $6 \mathrm{CH}, 12 \mathrm{CH}$, $24 \mathrm{CH}, 36 \mathrm{CH}$, and $48 \mathrm{CH}$ dynamizations, respectively. Likewise, Phosphorus $36 \mathrm{CH}$ was the least effective for AUDPC and the only treatment that, as well as the control group, resulted in $100 \%$ plant mortality by white mold. Regarding $6 \mathrm{CH}, 12 \mathrm{CH}$, $24 \mathrm{CH}$, and $48 \mathrm{CH}$ dynamizations, reductions in plant mortality were $60,90,60$, and $90 \%$, respectively, in comparison to the control group. These results emphasize the importance of testing several dynamizations for a same remedy, since their responses are not linear.

In the test to evaluate the control of white mold by Calcarea carbonica, the two variables were significant (Table 2). For AUDPC, only the dynamization $6 \mathrm{CH}$ had a similar action than that of the control treatment, so that the disease progression reduced by about $25 \%$ for $24 \mathrm{CH}$ and $36 \mathrm{CH}$ dynamizations, and by $83 \%$ for $12 \mathrm{CH}$ and $48 \mathrm{CH}$ ones.

The extremely diluted solutions of Calcarea carbonica $12 \mathrm{CH}$ and Calcarea carbonica $48 \mathrm{CH}$ reduced white mold progression by about $77 \%$ when compared to Calcarea carbonica $6 \mathrm{CH}$, Calcarea carbonica $24 \mathrm{CH}$ and Calcarea carbonica $36 \mathrm{CH}$. These data suggest a satisfactory white mold control only for Calcarea carbonica $12 \mathrm{CH}$ and Calcarea carbonica $48 \mathrm{CH}$.

Likewise, in the second test, Calcarea carbonica $12 \mathrm{CH}$ and Calcarea carbonica $48 \mathrm{CH}$ stood out, with reductions by 81 and $74 \%$, respectively, in disease progression. Similar results were observed for PDP, with reductions by $85 \%$ for Calcarea carbonica $12 \mathrm{CH}$ and $80 \%$ for Calcarea carbonica $48 \mathrm{CH}$. The other treatments also decreased plant mortality, but not expressively, so that Calcarea carbonica $6 \mathrm{CH}$ and Calcarea carbonica $36 \mathrm{CH}$ did not differ from the control group. A difference was observed for Calcarea carbonica $24 \mathrm{CH}$, but the reduction was only by $40 \%$.

These results indicate that the extremely diluted solutions chosen for this study are correct, but the dynamizations $6 \mathrm{CH}$, $24 \mathrm{CH}$ and $36 \mathrm{CH}$ were not suitable for pathological conditions. Thus, it must be emphasized again the importance of using several dynamizations, since responses may vary depending on drug potency (Bonato, 2007b). Furthermore, by acting on the vital energy, which is a dynamic principle, immaterial, distinct from the body and that integrates the entire body, organizing all physiological phenomena (Bonato, 2007a), the same remedy may be applicable to several bodies and under different situations.

Fonseca et al. (2006) evaluated the effect of a unique application of Calcarea carbonica in Porophyllum ruderale ("arnica-paulista") plants and observed an increase in leaf polyphenol concentrations, proving the resistance inducing activity of homeopathic remedies. Calcarea carbonica has also been mentioned by its inhibitory effect on ethylene production in tomato fruits, by delaying the proportion of fruit sauce and increasing the percentage of salad and colorful fruits (Modolon et al. 2012). Since ethylene is a hormone whose growth favors the onset of symptoms of white mold (Al-Masri e Barakat, 2003), a reduction in its synthesis on common bean plants treated with Phosphorus and Calcarea carbonica could be a hypothesis for the efficiency observed in the control of this disease.

Briefly, at the end of the tests, the replicates of the control treatment presented $100 \%$ plant mortality, while those treated with Phosphorus and Calcarea carbonica, both potentiated at $12 \mathrm{CH}$ and $48 \mathrm{CH}$, showed resistance to disease progression, emphasizing their role in inducing resistance. Similarly, Leonel and Barros (2013) observed the control of coffee rust up to three months after application of homeopathic remedies in plants affected by such a disease, confirming their residual effect.

In general, in trials carried out in the present study, plants apparently did not respond linearly to the tested dynamizations. The same substance able to increase the values of AUDPC and PDP also showed suppressive effect under different dynamizations, so that a same substance can be innocuous or efficient for a variable according to changes in its dynamization.

In plants, studies have demonstrated that an increase in dynamizations does not necessarily mean an increase in drug potency (Bonato, 2007b). Andrade et al. (2012) obtained sinusoidal patterns after evaluating the effect of increasing dynamizations of Arnica montana on the coumarin content of Justicia pectoralis ("chambá") plants. Likewise, Toledo et al. (2015) evaluated the effects of the homeopathic remedies Propolis, Sulphur and Ferrum sulphuricum at $6,12,30$, and $60 \mathrm{CH}$ dynamizations and obtained a sinuous pattern in response to the severity of early blight in tomato, as well as for plant growth variables. This fact, as proven by several researchers and for different 
Table 1. Area under the disease progress curve (AUDPC) and percentage of dead plants (PDP) of common bean treated with extremely diluted aqueous solutions of Phosphorus at different dynamizations

\begin{tabular}{lccccc}
\hline Phosphorus & \multicolumn{3}{c}{ Test 1 } & \multicolumn{2}{c}{ Test 2 } \\
\cline { 2 - 3 } \cline { 5 - 6 } Dynamization (CH) & AUDPC & PDP & & AUDPC & PDP \\
\hline 6 & $08.79 \mathrm{~B}$ & $40 \mathrm{AB}$ & & $10.05 \mathrm{CD}$ & $40 \mathrm{~B}$ \\
12 & $06.15 \mathrm{~A}$ & $10 \mathrm{~A}$ & & $07.08 \mathrm{~A}$ & $10 \mathrm{~A}$ \\
24 & $08.59 \mathrm{~B}$ & $30 \mathrm{AB}$ & & $09.41 \mathrm{BC}$ & $40 \mathrm{~B}$ \\
36 & $11.34 \mathrm{C}$ & $75 \mathrm{BC}$ & & $11.70 \mathrm{D}$ & $100 \mathrm{C}$ \\
48 & $06.22 \mathrm{~A}$ & $20 \mathrm{~A}$ & & $07.63 \mathrm{AB}$ & $10 \mathrm{~A}$ \\
\hline Controle & $14.65 \mathrm{D}$ & $100 \mathrm{C}$ & & $15.75 \mathrm{E}$ & $100 \mathrm{C}$ \\
\hline CV (\%) & 09.59 & 54.55 & 10.27 & 25.86 \\
\hline
\end{tabular}

Averages followed by the same letter in the column. do not differ significantly by Tukey test $(p<0.05)$.

Table 2. Area under the disease progress curve (AUDPC) and percentage of dead plants (PDP) of common bean treated with extremely diluted aqueous solutions of Calcarea carbonica at different dynamizations

\begin{tabular}{lccccc}
\hline \multicolumn{2}{c}{ Calcarea carbonica } & \multicolumn{3}{c}{} \\
\cline { 1 - 3 } Dynamization (CH) & AUDPC & PDP & & AUDPC & PDP \\
\cline { 2 - 3 } \cline { 5 - 6 } & $11.06 \mathrm{C}$ & $70 \mathrm{~B}$ & & $10.42 \mathrm{~B}$ & $80 \mathrm{BC}$ \\
12 & $02.63 \mathrm{~A}$ & $15 \mathrm{~A}$ & & $02.93 \mathrm{~A}$ & $15 \mathrm{~A}$ \\
24 & $10.95 \mathrm{~B}$ & $70 \mathrm{~B}$ & & $12.17 \mathrm{~B}$ & $60 \mathrm{~B}$ \\
36 & $10.39 \mathrm{~B}$ & $90 \mathrm{~B}$ & & $11.45 \mathrm{~B}$ & $80 \mathrm{BC}$ \\
48 & $02.34 \mathrm{~A}$ & $20 \mathrm{~A}$ & & $04.06 \mathrm{~A}$ & $20 \mathrm{~A}$ \\
\hline Control & $14.65 \mathrm{C}$ & $100 \mathrm{~B}$ & & $15.75 \mathrm{C}$ & $100 \mathrm{C}$ \\
\hline CV (\%) & 11.03 & 38.26 & 8.89 & 33.18 \\
\hline
\end{tabular}

Averages followed by the same letter in the column. do not differ significantly in the Tukey test $(p<0.05)$.

Table 3. Area under the curve of mycelial growth (AUCMG) and number of sclerotia (NS) of Sclerotinia sclerotiorum treated with extremely diluted aqueous solutions of Phosphorus at different dynamizations.

\begin{tabular}{ccc}
\hline Phosphorus & \\
\hline Dynamization (CH) & AUCMG & NS \\
\hline 6 & $09.04 \mathrm{~A}$ & $41.00 \mathrm{~B}$ \\
12 & $07.68 \mathrm{~A}$ & $21.25 \mathrm{~A}$ \\
24 & $12.56 \mathrm{~B}$ & $40.50 \mathrm{~B}$ \\
36 & $13.09 \mathrm{~B}$ & $22.25 \mathrm{~A}$ \\
48 & $06.98 \mathrm{~A}$ & $21.00 \mathrm{~A}$ \\
\hline Control & $13.55 \mathrm{~B}$ & $23.50 \mathrm{~A}$ \\
\hline CV(\%) & 08.83 & 08.73 \\
\hline Averages followed by the same letter in the column. do not differ significantly by Tukey test $(\mathrm{p}<0.05)$.
\end{tabular}

Table 4. Area under the curve of mycelial growth (AUCMG) and number of sclerotia (NS) of Sclerotinia sclerotiorum treated with extremely diluted aqueous solutions of Calcarea carbonica at different dynamizations.

\begin{tabular}{lcc}
\hline Calcarea carbonica & \\
\hline Dinamization (CH) & AUCMG & NS \\
\hline 6 & $11.76 \mathrm{C}$ & $43.50 \mathrm{CD}$ \\
12 & $08.27 \mathrm{~B}$ & $20.50 \mathrm{~B}$ \\
24 & $11.94 \mathrm{C}$ & $41.50 \mathrm{C}$ \\
36 & $11.14 \mathrm{C}$ & $47.75 \mathrm{D}$ \\
48 & $02.42 \mathrm{~A}$ & $00.00 \mathrm{~A}$ \\
\hline Control & $14.05 \mathrm{D}$ & $23.50 \mathrm{~B}$ \\
\hline CV(\%) & 08.09 & 08.72 \\
\hline Averages followed by the same letter in the column. do not differ significantly by Tukey test $(\mathrm{p}<0.05)$.
\end{tabular}


variables (Bonato et al., 2009; Andrade et al., 2012; Rissato et al., 2016), indicates that the same homeopathic remedy may act differently on a same variable, which can be increased or inhibited depending on the dynamization. Thus, in the present study, regression analysis was not performed for treatments with different dynamizations.

On the above basis, it should also be emphasized that healing with homeopathy is based predominantly on Similar Law and vitalism. Thus, from the homeopathic point of view, healing occurs when the vital force that distinguishes living beings (animals and plants) from inanimate objects is reestablished, leading to the conclusion that a similarity exists between plants presenting white mold and the remedies Phosphorus and Calcarea carbonica.

\section{Fungitoxic activity}

With respect to the development variables of $S$. sclerotiorum, the treatment Phosphorus led to differences for mycelial growth, expressed as area under curve of the mycelial growth (AUCMG) (Table 3 ) at $6 \mathrm{CH}, 12 \mathrm{CH}$ and $48 \mathrm{CH}$ dynamizations, when compared to the control group, so that 33,43 and $48 \%$ delays were observed, respectively. The dynamizations $24 \mathrm{CH}$ and $36 \mathrm{CH}$ had no antimicrobial potential. Regarding the number of sclerotia (NS), Phosphorus $6 \mathrm{CH}$ and Phosphorus $24 \mathrm{CH}$ stimulated sclerotial formation by 74 and $72 \%$, respectively, when compared to the control group. For all other dynamizations, NS did not differ from the treatment with hydroalcoholic solution (30\%), indicating a probable effect of alcohol on sclerotial formation. The treatment Calcarea carbonica (Table 4), at $12 \mathrm{CH}$ and $48 \mathrm{CH}$ dynamizations, reduced the mycelial growth of $S$. sclerotiorum by 41 and $83 \%$, respectively. The other treatments differed from the control group, but with a low antimicrobial potential, not extending beyond $21 \%$ mycelial growth inhibition, which indicates that the antifungal activity of Calcarea carbonica is directly related to its energy property. The results obtained for NS (Table 4) demonstrate the importance of using an appropriate dynamization. Calcarea carbonica at $6 \mathrm{CH}, 24 \mathrm{CH}$ and $36 \mathrm{CH}$ led to differences, with increases in NS by 85, 77 and 103\%, respectively, when compared to the control group. Conversely, Calcarea carbonica $48 \mathrm{CH}$ inhibited sclerotial formation. Thus, Calcarea carbonica $48 \mathrm{CH}$ emerges as an alternative for integrated control of $S$. sclerotiorum since it slows down the exponential growth of the pathogen over the years, so that NS can be reduced by up to $100 \%$. Although some tested treatments did not result in differences, their potential should not be disregarded. Thus, further studies involving dosage, dynamization, method, and application frequency of extremely diluted solutions are needed.

\section{Materials and Methods}

\section{Choice and preparation of treatments}

Extremely diluted solutions were selected by repertorization through the software HomeoPro and chosen with the assistance of the Homeopathic Materia Medica (Boerick, 2003). For this purpose, the symptoms of plants infected by $S$. sclerotiorum and environmental conditions favoring its occurrence were considered, i.e. deep epidermal lesions, especially in the lower members, and plant injury and chlorosis favored by high humidity. The Homeopathic Materia Medica (Boericke, 2003) describes the individual to Calcarea carbonica as light sensitive, as well as the pathogen S. sclerotiorum, which has skin warts and rashes difficult to heal, similarly to the symptoms presented by plants affected by the fungus; and that has difficulty to swallow, as well as the plant to absorb water and nutrients. Phosphorus has already been recommended for individuals presenting degeneration of blood vessels, skin lesions and destructive metabolic conditions (Boericke, 2003). Thus, Phosphorus and Calcarea carbonica were chosen.

Based on previous studies, which reported positive responses regarding induced resistance in plants against pathogens by using extremely diluted solutions (Toledo et al., 2009; Modolon et al., 2012; Rissato et al., 2016), the dynamizations $6 \mathrm{CH}, 12 \mathrm{CH}, 24 \mathrm{CH}, 36 \mathrm{CH}$, and $48 \mathrm{CH}$ (centesimal Hahnemannian) were chosen for this work. The hydroalcoholic solution (ethanol $30 \%$ ) was considered as the control group since it was the diluent used to prepare such remedies.

The remedies were obtained from a homeopathic pharmacy at $6 \mathrm{CH}$ dynamization and manipulated to 12,24 , 36 , and $48 \mathrm{CH}$ in accordance with the Brazilian Homeopathic Pharmacopoeia (1997) by dilution at $1: 100$ and succussing 100 times. After, the pluralist dilution proposed by Hahnemann was followed, so that a flask was used for each dilution and suction was applied in unidirectional, sequential and vertical movements through a mechanical stirrer. Each remedy was diluted in distilled water at $0.1 \%$ ratio at the time of its use, according to Bonato et al. (2009).

\section{Resistance inducing activity evaluation}

The experiment was carried out in an acclimatized greenhouse in a completely randomized design, with four tests involving six treatments and five replicates each. The first two tests were carried out simultaneously in June and July 2015, each one of them using Phosphorus and Calcarea carbonica in their respective dynamizations. The following two tests were carried out similarly to the previous ones, from November to December 2015, in order to impart the results obtained in the first cycle. Common bean seeds (cultivar 'IAC Alvorada') were sanitized in alcohol $70 \%$ for 1 min and in sodium hypochlorite solution (3:1) for 2 min, followed by rinsing with distilled water. Seeds were placed into acrylic boxes (Gerbox) filled with three paper sheets (Germitest ${ }^{\circ}$ ) moistened with distilled water. After, seeds were maintained in a BOD (Bio-Oxygen Demand) incubator at $25^{\circ} \mathrm{C}$ in a $12 \mathrm{~h}$-light/ $12 \mathrm{~h}$-dark photoperiod, and aside for the final seeding after three days. Seeds presenting no pathogens and with full and proportional radicles were selected for greenhouse experiments. Sowing was performed in 31 pots filled with a mixture of soil and sand (2:1) previously autoclaved at $120^{\circ} \mathrm{C}$ for $60 \mathrm{~min}$. Each pot contained six seedlings. At the V1 stage, a thinning was done in order to maintain three seedlings per pot. When plants presented their first fully expanded trifoliate leaf (V2 stage), two segments of common beans ( $2 \mathrm{~mm}$ diameter) replete with $S$. sclerotiorum mycelia were inoculated at the base of each plant. The treatments $(0.1 \%)$ were administered in the soil three days before inoculation, on the day of inoculation, and at 3,10 and 17 days after inoculation. Lesions caused by 
S. sclerotiorum were measured daily through a caliper as soon as the first symptoms appeared at the base of plants, so that measurements ceased when control plants were dead. For each treatment, the values of the area under the disease progress curve (AUDPC) were obtained through the equation of Shaner and Finney (1977):

$$
\begin{aligned}
A U D P C=\llbracket \frac{\left(Y_{1}+Y_{1+1}\right)}{2} * I \rrbracket \\
+\llbracket \frac{\left(Y_{2}+Y_{2+1}\right)}{2} * I \rrbracket \cdots \llbracket \frac{\left(Y_{n}+Y_{n+1}\right)}{2} \\
* I \rrbracket
\end{aligned}
$$

Where:

AUDPC $=$ area under the disease progress curve (adimensional);

$Y_{i}$ and $Y_{i+1}=$ size of lesion of the disease observed in two consecutive evaluations $(\mathrm{cm})$;

$\mathrm{I}$ = interval between two consecutive evaluations (days).

The evaluation of plant mortality from white mold disease took place after the tests were completed when the number of dead plants per treatment was counted. The percentage of dead plants (PDP) was obtained through the equation:

$$
P D P=\frac{N D P}{\mathrm{TNP}} * 100
$$

Where:

PDP = Percentage of dead plants for the treatment in question;

NDP = Number of dead plants in the treatment;

TNP $=$ Total number of plants in the treatment.

\section{Fungitoxic activity evaluation}

The experiment was carried out in a completely randomized design, totaling two tests involving six treatments and five replicates each. The first test was carried out with the Phosphorus treatment, and the second one with Calcarea carbonica, both at $6 \mathrm{CH}, 12 \mathrm{CH}, 24 \mathrm{CH}, 36 \mathrm{CH}$, and $48 \mathrm{CH}$ dynamizations. For evaluation of the in vitro activity, the treatments $(0.1 \%)$ under appropriate dynamizations were added to Erlenmeyer flasks containing autoclaved potato dextrose agar (PDA) culture medium. The whole process was occured within a laminar flow chamber. After a complete culture medium solidification, each Petri dish received a disc (7 $\mathrm{mm}$ diameter) containing $\mathrm{S}$. sclerotiorum mycelia in its center. Then, Petri dishes were sealed with plastic wrap and maintened in BOD incubator at $25^{\circ} \mathrm{C}$ in the absence of light. For evaluation of mycelial growth, daily measurements were performed by the method of diametrically opposed measures, beginning at $24 \mathrm{~h}$ after experiment installation and lasting until when fungal colonies eached the edges of Petri dishes. After the end of the experiment, the area under curve of the mycelial growth (AUCMG) was calculated according to the equation of Shaner and Finney (1977). The number of sclerotia (NE) was measured 30 days after the test assembly.

\section{Statistical analysis}

To analyze the data, an analysis of variance (ANOVA) was performed and, when relevant, the Tuley test at 5\% probability of error was conducted using the statistical program GENES (Cruz, 2006).

\section{Conclusion}

The extremely diluted solutions Phosphorus $12 \mathrm{CH}$, Phosphorus $48 \mathrm{CH}$, Calcarea carbonica $12 \mathrm{CH}$ and Calcarea carbonica $48 \mathrm{CH}$ showed potential to control the white mold bean, as well as antimicrobial activity against Sclerotinia sclerotiorum.

\section{References}

Al-Masri MI, Barakat R (2003) Role of the auxin, Naphthalene Acetic Acid (NAA) in the pathogenicity of Sclerotinia sclerotiorum, causative organismo of white mold disease. HU Res J. 1(2): 4-15.

Andrade FMC, Casali VWD, Cecon PRC (2012) Efeito de dinamizações de Arnica montana L. no metabolismo de chambá (Justicia pectoralis Jacq.). Rev Bras Plantas Med. 14: 159-162.

Boericke WO (2003) Manual de Matéria Médica Homeopática. São Paulo.

Bonato CM, Silva EP (2003) Effect of the homeopathic solution Sulphur on the growth and productivity of radish. Acta Sci Agro. 25(2): 259-263.

Bonato CM, (2007a). Effect of the homeopathy in the host physiology. Fitopatol Bras. 35: 17-20.

Bonato CM (2007b) Homeopatia em modelos vegetais. Cult Homeopa. 2: 24-28.

Bonato CM, Proença GT, Reis B (2009) Homeopathic drugs Arsenicum album and Sulphur affect the growth and essential oil content in mint (Mentha arvensis L.). Acta Sci Agro. 31(1): 101-105.

Cruz CD (2006) Programa Genes: Biometria. Viçosa: Editora UFV.

Fancelli AL, Dourado Neto D (2007) Produção de Feijão. Piracicaba.

Fonseca MCM, Casali VWD, Cecon PR (2006) Efeito de aplicação única dos preparados homeopáticos Calcarea carbonica, Kalium phosphoricum, Magnesium carbonicum, Natricum muriaticum e Silicea terra no teor de tânico em Porophyllum ruderale (Jacq.) Cassini. Cult Homeopa. 4(6): 6-8.

Leonel AH, Barros BHR (2013) Utilização de preparados homeopáticos para controle da ferrugem do café (Hemileia vastatrix) na região da Alta Mogiana. Aba agroecologia, 8(2): 1-5.

Lisboa SP, Cupertino MC, Arruda VM, Casali VWD (2005) Nova visão dos organismos vivos e o equilíbrio pela homeopatia. Viçosa.

Modolon TA, Boff P, Rosa JM, Sousa PMR, Miquelluti DJ (2012) Qualidade pós-colheita de frutosde tomateiro submetidos a preparados em altas diluições. Hort Bras. 30(1): $58-63$.

Napoleão R, Café-Filho AC, Nasser LCB, Lopes CA, Silva HR (2005) Intensidade do mofo-branco do feijoeiro em plantio convencional e direto sob diferentes lâminas d'água Fitopatol Bras. 30: 374-379.

Pereira FS, Borges LP, Guimarães GR, Silva A, Gonçalves RN, Carvalho LR, Teixeira, IR (2013) Estratégias de controle de mofo branco do feijoeiro. Centro Científico Conhecer, 9(17): 1354-1371. 
Rissato BB, Stangarlin JR., Coltro-Roncato S, Dildey ODF, Gonçalvez EDV, Broetto L, Kuhn OJ, Lorenzetti E, Mioranza T, Figueira EPP, Webler TFB, Laureth JCU (2016) Control of white mold in bean plants by homeopathic medicines. Afr J Agric Res. 11(24): 2174-2178.

Shaner G, Finney RE (1997) The effects of nitrogen fertilization on the expression of slowmildwing in knox wheat. Phytopathol. 67: 1051-1055.

Toledo MV, Stangarlin JR, Bonato CM (2009) Uso dos Medicamentos Homeopáticos Sulphur e Ferrum sulphuricum no Controle da Doença Pinta Preta em Tomateiro. ABA Agroecologia. 4(2): 475-478.

Toledo MV, Stangarlin JR, Bonato CM (2015). Controle da pinta preta e efeito sobre variáveis de crescimento em tomateiro por preparados homeopáticos. Summa Phytopathol. 41(2): 126-132.

Vieira C, Paula Júnior TJ, Borém A. 2007. Feijão. Viçosa.

Wassenhoven VM (2007). Evidence of the effectiveness of homeopathy. Cult Homeopát. 20: 27-31. 